\title{
Employability of Graduates from Kenyan Universities: The Employer's Perspective
}

\author{
Dr. Joseph K. Kirui \\ School of business and Economics, \\ University of Kabianga
}

\begin{abstract}
Employability of graduates, a key dimension of quality and relevance of any system of education has come under sharp focus in Kenya. Judging from the many concerns raised by employers about the need to retrain new graduate entrance to the employment sector, aspersion is being cast on the quality and relevance of University education. This study, therefore, sought to answer this by investigating the level of employability skills possessed by university graduates from the perspective of employers. The study was grounded on Human capital theory and adopted a triangular design which sought views from three different groups one of them being employers in Kericho county totaling 86. All employers were selected to take part in this study. Data was collected through the use of questionnaires. Multiple linear regressions was used to assess the objectives respectively. Employers recognize literacy \& numerical skills, critical thinking skills, interpersonal skills, and work ethics as the key skills defining current graduate's employability. Employers, the direct consumers of the graduates from universities in Kenya holds a positive view towards the levels of employability among Kenyan graduates, with the ratings in various skills being above average. This is contrary to the often peddled belief that Kenyan graduates are ill prepared to face the challenges in the work industry. In recognition that not every graduate will be an entrepreneur, inculcating the right skills going forward will be critical for graduates to remain employable. While most universities in Kenya are more focud on training graduates who are skilled in their technical areas and specialization, more focus should be on soft skills.
\end{abstract}

Keywords: Employability of graduates, Employers, Kericho county, Kenya,

DOI: $10.7176 / \mathrm{JRDM} / 54-05$

Publication date: April $30^{\text {th }} 2019$

\section{INTRODUCTION}

Education at macro-level, is known to create superior human capital, an important factor in social and economic development of any country and at micro-level, among others, it enhances individual potential in terms of employability, entrepreneurship, self understanding and the way we look at the world (Oztruk 2001). In fact, education has been known to impact on several spheres of human life notably income distribution, healthcare, security, national cohesion, political process and unemployment (Organization for Economic Cooperation and development [OECD], 2014).

Education generally and university education in particular in conjunction with other factors of production has been considered as the best engine that can spur economic growth and development of any country, a viewpoint that economists are in consensus with (Theodore, 2012). This is because education coupled with training enhances productive capacity of the fourth and vital factor of production, the Human Capital. Specifically, the level of education which play catalytic role in the process of social and economic transformation, is the university education (Nyangau, 2014).

Faced with a surging population of persons aged below 35 years and increased demand for university education, most African countries, including Kenya, have responded by significantly expanding the university sector (Oanda \&Sifuna, 2016). Prior to the nineteenth century, investment in education was not considered a priority but in the $21^{\text {st }}$ century, this has since radically changed with most governments now putting emphasis on investment in education including tertiary and higher education (Oztruk, 2001).

Higher education and specifically university education must be of the right quality and appropriate to the needs of the consumers of that education so as to impact on economic and social fabric of the individual and society at large (Nyangau, 2014; Nganga, 2014; Amimo, 2012). For many countries the question now is not so much providing education, but ensuring its quality and equity of access regardless of gender and socio-economic status (OECD, 2012). The concept of quality and relevance of education cannot be seen in a vacuum neither can it be seen through a universal lens. It cannot also be considered as a static concept. The concept is contextual as education that is quality and relevant in one country may not be so in another country and even in the same country, quality and relevance of education cannot remain static over time. It is the appreciation of this reality that calls for customization of viewing the quality and relevance of education system in the context that obtains in any country.

As the number of universities grow exponentially, so are the number of graduates being released into the labor market annually by these Universities resulting in a significant proportion of these graduates being 
unemployed. In 2016 all the 30 public and 32 private universities in Kenya and their extensions cumulatively churned out 50,000 plus graduates into the labor market up from 460 in 1970 (www.uonbi.ac.ke). This is by no means a big number for Kenya's mainly agro-based economy with small manufacturing and service sector growing at an annual rate averaging 5\% (KNBS, 2016).

\section{Statement of the problem}

It is a fact that the fletchling economy of Kenya cannot absorb all graduates produced by all universities in Kenya at any given time, but for those who succeed in joining formal employment, it is the expectation of their employers that as they exit their respective universities to join the industry, with adequate orientation, they will perfectly fit the existing jobs in the industry. For those who may not succeed in joining the formal sector, it is expected that they should use university skills and knowledge acquired to create for themselves some source of livelihood.

However, concern has been raised as to the ability of fresh graduates to fit well into the requirements of the industry or in the absence of formal jobs, their willingness and orientation to venture into self employment (assuming other factors are held constant such as availability of venture capital and business opportunities).

Employers are on record expressing concern that majority of Kenyan graduates are not employable as they are ill prepared to face the challenges of workplace. It is also worrisome that hundreds of thousands of graduates who don't succeed in getting jobs remain jobless many years after their graduation and not venturing into self employment as an alternative. Thecomplains of Employers and concerns of the society raises pertinent questions as to the quality and relevance of university education in Kenya. University education may not only be producing graduates whose employability skills do not meet the expectation of potential employers, but ill prepared and lack the motivation and culture to venture into own businesses.

This study, therefore, sought to investigate the graduate's satisfaction level with the quality and relevance of university education they received, the entrepreneurial culture inculcated in them and level of employability skills they possess.

The results of this study may help to inform design of academic programs and pedagogical approaches suitable to enhance graduate employability, entrepreneurial culture and enhance the level of satisfaction of subsequent students with university education.

\subsection{Study objective and hypothesis}

The purpose of this study was to establish the skills influencing employability of university graduates in Kenya The hypothesis arising from the objective of this study is:

$\mathrm{H}_{0} 3$ : Skills acquired by graduates in private and public universities in Kenya do not influence their employability.

\subsection{LITERATURE REVIEW}

The headache that most employers have to grapple with nowadays is not that fresh graduates are not highly educated, but the fact that they are not employable and they are not employable not because there are no job completely for them, their unemployment may be due to their failure to match the jobs that exist or meet the minimum requirements for those particular jobs. A study in the US by North West Regional Educational Laboratory, (1993) revealed that employers' dissatisfaction with young job applicants is not primarily due to inadequate technical knowledge or skill but their lack of employability skills. No wonder, a significant number of graduates cannot easily find jobs, and are often forced to compete for lower skilled jobs (Amimo, 2012). Similarly IES (2015) found out that graduates are not only increasingly entering non-graduate jobs but also jobs that did not fully utilize their skills.

It is also not uncommon for graduates from the same disciplinary backgrounds to take different time in their entry into employment relationship. These two situations are attributable to differences in employability potentials of graduates. The term employability has been variously defined by different scholars and below are a few examples." Yorke and Knight (2003) defined the concept of employability as "a set of achievements, understandings and personal attributes that make an individual more likely to gain employment and be successful in their chosen occupations". The Institute of Employment Studies (1998)definition of employability is "the capacity to move self sufficiently within the labour market to realise potential through sustainable employment...for the individual it depends on the knowledge, skills and attributes they posses, the way they use those assets and present them to employers", while Confederation of British Industry (CBI) / National Union of Students (NUS) (2011) defined employability as "A set of attributes, skills and knowledge that all labour market participants should possess to ensure they have the capability of being effective in the workplace - to the benefit of themselves, their employer and the wider economy".

A critical synthesis of these definitions reveal that technical skills is inherently subsumed to exist in the individual and their employability is how they utilize them to achieve the goals of the job and demonstrate to others that they have these skills through communication. Sometimes it is easy to incorrectly assume that a 
highly educated society has many employable people but not all countries with the largest increase in educational attainment rates are those with the largest increase in the proportion of highly skilled adults (OECD, 2014). The situation in the labor market is more complex than simply possessing extra credentials and technical knowledge from higher education (Tomlinson, 2008)

In a study by UNESCO (2012) on employability of graduates covering three Asian countries, Malaysia, Indonesia and Philippines, involving 626 respondents spread across all the three countries, the findings differed in the three coutries. In Indonesia, the study concluded that employability is not about only training or providing additional skills to gain employment; it should also be about how the higher education system through its many institutions develops critical, reflective and empowered learners who will be highly sought after and valued by employers.

In Malaysia, the study adopted qualitative approach where 11 focus groups comprising of 8-12 members each took part in the study. The membership comprised of employers of various sizes, Malaysia employers federation, graduate students (both employed and looking for employment) and faculty staff, education administrators, The findings indicated that Employers and the Federation of Malaysian Manufacturers/Small Medium Industries (FMM/SMI) were in agreement as to the unsuitability of graduates for the jobs available which in the opinion of Malaysian Employers Federation (MEF) was a major issue for Malaysia. Unemployed graduates' responses as to why they were unemployed indicated that they felt they did not satisfy job requirements in terms of their academic qualifications, skills and competencies. In addition, graduates felt that their lack of experience and their families' socio-economic background were factors leading to unemployment . Further results in the same study showed that According to both Non Governmental Organisations (NGOs) and industry employers, employable graduates are those who are prepared to work, have the appropriate skills and competencies, and the ability to learn and re-learn. NGOs listed humanitarian values (honesty, caring, patience) and socially-desirable attitudes (open, curious and confident) as the key characteristics of employability. Employers, on the other hand, listed attitudes such as preparedness, positivity, interest, dedication, team spirit, and readiness to face challenges and hardship, and work-related competencies such as the ability to apply theory in the working environment and communication skills as important characteristics and qualifications as an important requirement for employability, but qualifications were not considered to be as important as attitude. Thus, the responses indicate that a high grade point average will not guarantee employability.

In Philippines the study involving 130 respondents revealed that graduate unemployment in the Philippines has largely been attributed to a structural or skills mismatch. This mismatch occurs because the jobseekers, in general, are not seen by employers as having the necessary skills for employment. One area of this mismatch lies in the inadequacy of the general skills and knowledge among new entrants to the labor force. New graduates are perceived to lack the requisite level and quality of communication, technical and job-specific skills needed in the workplace. Another mismatch can be found in the disparity between the type of graduates or trainees produced and the type of jobs available.

The respondents in all the three countries who participated in co-curricular activities perceived that their involvement in these activities had produced beneficial outcomes as follows: (a) the opportunity to work in various work sectors; (b) the opportunity to play an effective role in community development; (c) enhanced leadership skills findings corroborated by Rosenberg, Heimler and Morote,(2012) (d) improved time management skills; (e) knowledge and skills relevant to their present job; (f ) improved communication skills; (h) increased teamwork spirit; and (i) better human relations skills

Washer (2007) in review of various qualification frameworks used across European countries, identified a number of key skills which students are expected to acquire as they pass through formal education at a higher level, these key skills include, communication skills, Numeracy skills, information technology skills, personal skills - (working with others); and personal skills (improving own learning and performance)

In a study involving 53 final year university students, Tomlinson (2008) found that most students view acquisition of university credentials as a precursor to enhancing ones employability. shows, higher education students view their credentials as positional that provide advantages in the labour market; however, there was also widespread concern abou their limitations. Students view the relationship between their higher education credentials their utility in the market as being far from straightforward. Accessing the types of employment and labour market returns they were seeking was therefore viewed as not being reducible higher education credentials (ibid)

It was apparent that students do not view their employability as being determined simply their by absolute level of credentials and the skills and knowledge engendered by these. The evidence here instead points to students' perception that the markers of their employability have changed, driven mainly by what they view as being an over-supply in gradu- ate talent leaving higher education (Tomlinson, 2008)

Supply-side factors contributed to the high numbers of unemployed graduates. The kind of skills required for graduates to enter the labour market need to be clearly understood so that higher education institutions (HEIs) can foster these skills in their students. Relevance of their programmes plays an important part in helping their 
graduates find employment. (UNESCO 2012)

According to OECD (2012) for education, whether secondary, vocational or tertiary, to be considered quality it should equip people with the skills actually needed in the workplace. Studies are abound in literature that suggests various employability skills which graduates must poccess to be employable. According to IES (2015) who suggested that among the skills required in workplace are generic and employability skills, Work experience was seen as especially useful in developing not only generic skills and personal maturity but also business or commercial understanding (IES, 2015) Washer, (2007) identified Communication skills, Working with others, Problem solving, Numeracy, The use of information technology, Learning how to learn, personal and professional development skills as important workplace skills. Tumuti, Mule, Gecaga and Manguriu (2013), on their part suggests that necessary employability skills include generic skills such as communication/interpersonal, learning, self-skills, networking, teamwork, problem-solving, and initiative skills while Humburg, van der Velden and Verhagen, (2013) identifies interpersonal skills (i.e communication skills, teamwork skills etc ), professional expertise and interpersonal skills, innovative/creative skills, strategic/organizational skills and commercial/entrepreneurial skills and General academic skills as key skills required by employers. These skills can be acquired by students through the use of problem-based learning, use of simulations, project work, simulations of workplace environments using computer assisted learning, dealing with 'mock' clients and so on (Bennett et al., 1999). However, Levy and Murnane reject the fact that computers will finally replace human labor; they spot such unique human skills, intellectual and emotional capabilities in the category of expert thinking and complex communication that can never be supplanted by computational technologies.

A study commissioned by World Bank and Kenya vision 2030 in 2014 on Youth Employment Initiatives in Kenya concluded that Kenya faces a significant unemployment problem with youth being hit hardest. The high unemployment is related to the overall investment climate in the country and the economy's low capacity to create new jobs. But youth find it particularly difficult to enter the labour market. Reasons for this are complex. They range from deficits in education and skills to lack of work experience, difficulties to obtain information about career options and job chances, and irrational recruitment practices of employers among other findings.

One problem with trying to equip graduates with the skills they will need in the workplace is that even graduates in the same field may find themselves working in very different settings (Washer, 2007). In view of the changes in the post industrial work place educators should "Practilize" their curriculum in order to produce graduates who will fit in the world of work (Amimo, 2012)

Graduates must be able to demonstrate that they possess skills that employers value (Washer, 2007). Specifically, educators are asked to respond to the question "What does it feel like to produce graduates whose employment is not guaranteed? This question is foundational and intentionally asked in this paper to awaken the responsibility and imagination of educators (Amimo, 2012).

But the data also show that educational attainment and skills do not always align. Moreover, not all countries with the largest increase in educational attainment rates are those with the largest increase in the proportion of highly skilled adults. In fact, across countries, adults with similar levels of education can have very different levels of proficiency in skills - a fact that argues for a reconsideration of how we define educational qualifications (OECD, 2014)

This point to the need for Universities to blend their curriculum with more practical content as opposed to relying mainly on theoretical classroom learning. The universities therefore should go to great lengths to interweave their courses with time spent in real or simulated work environments (Candy \& Crebert, 1991). In addition to employability skills identified by Tumuti et al (2013), Washer (2007) identified two other skills considered vital for employability of graduates; Numeracy and Information Technology.

The risks - and, in many instances, also the penalties - of low educational attainment and low skills pertain not only to income and employment, but to many other social outcomes as well. For example, there is a 23 percentage-point difference between the share of adults with high levels of education who report that they are in good health and the share of adults with low levels of education who report so. world Levels of interpersonal trust, participation in volunteering activities, and the belief that an individual can have an impact on the political process are all closely related to both education and skills levels. Thus, societies that have large shares of lowskilled people risk a deterioration in social cohesion and well-being. When large numbers of people do not share the benefits that accrue to more highly skilled populations, the long-term costs to society - in healthcare, unemployment and security, to name just a few - accumulate to become overwhelming. (OECD, 2014). In fact, across countries, adults with similar levels of education can have very different levels of proficiency in skills - a fact that argues for a reconsideration of how we define educational qualifications. (OECD, 2014)

Though there are many studies abroad that have studied employability of graduate employees based on opinions of employers on how graduate employees actually perform such as (Rosenberg, Heimler and Morote 2012; UNESCO 2012; IEC, 2015 and Ume-Amen, 2014 ), there are no studies in Kenya which have studied the actual qualities in terms of skills which employees are expected to have. All the studies that have attempted to 
study the quality and relevance of university education in Kenya are mostly desk researches that collated views in literature about employability of graduates and dimensions of quality education (Nyangau, 2014; Nganga, 2014; Amimo, 2012 and Abagi, Nzomo and Otieno, 2005).

\subsection{Human capital theory}

As a framework to underpin the studying of employability of graduates from Kenyan universities, the human capital theory whose proponents include Schults, (1961), Becker (1964) and others, was adopted.

The human capital of any organization consists of the people who work there and on whom the success of the business depends (Armstrong, 2006). This vital and unique resource is created through education particularly at the higher/university level where skills and abilities required by employers are imparted. Human capital is defined by Swanson (2001) as the knowledge, expertise and skills one accumulates through education and training. Accordiing to Bontis, Dragonetti, Jacobsen and Roos (1999) Human capital represents the human factor in the organization; the combined intelligence, skills and expertise that gives the organization its distinctive character and the human elements of the organization are those that are capable of learning, changing, innovating and providing the creative thrust which if properly motivated can ensure the long-term survival of the organization

The human capital theory is based on three relationships that are assumed to exist (see figure 2.2 below).

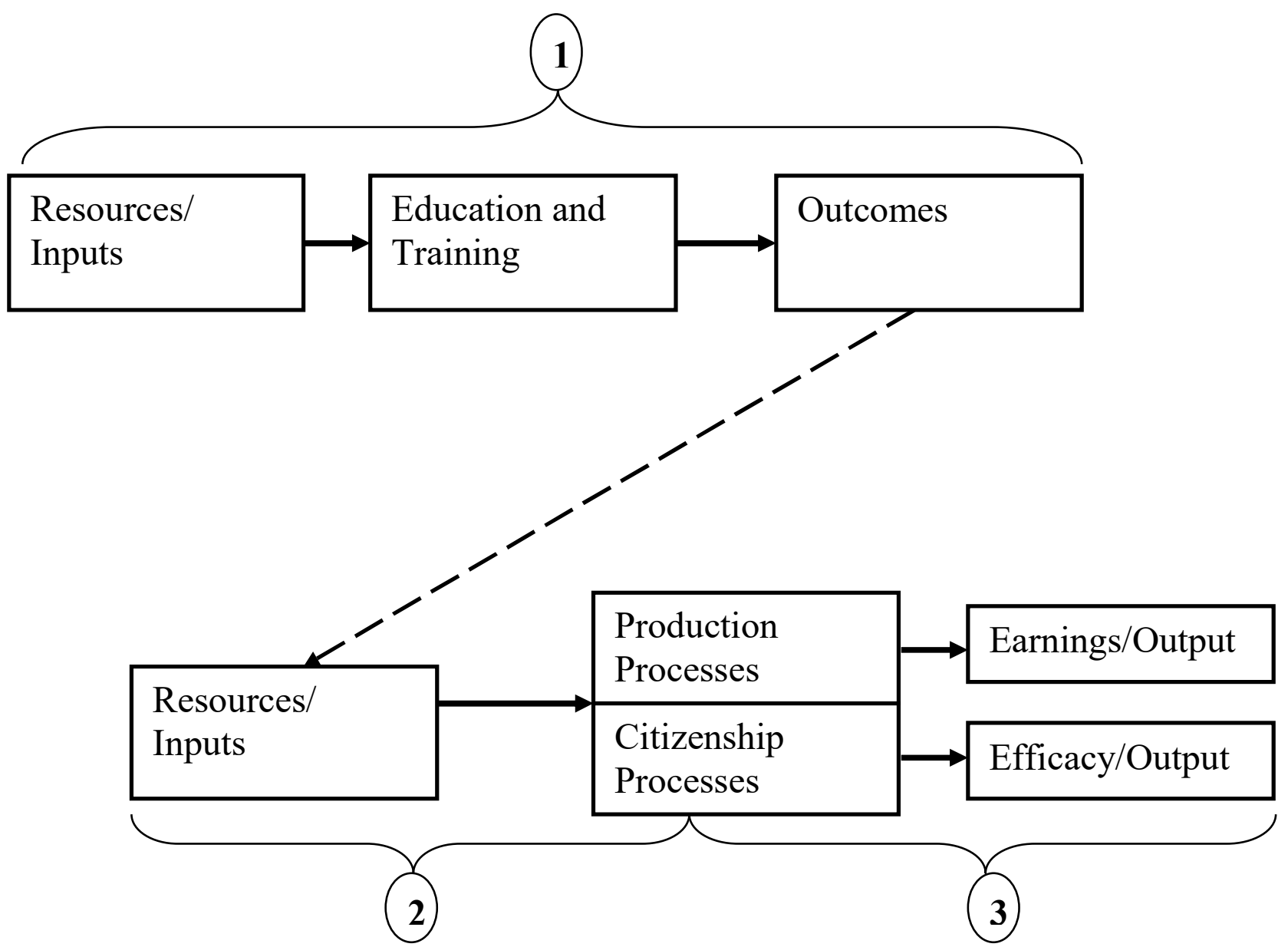

FIG 2.2: A model of human capital theory

Source: Swanson, 2001

In the tigure above, Kelationship I reters to the concept of production functions as applied to education and training. This relationship shows that when resources/ input (human factor) is educated and trained, learning takes place and the outcome is human capital (people with skills, knowledge and capabilities). Relationship 2 
represents the human capital relationship between learning and increased productivity. In this relationship, employees who undergo education and training acquire skills, knowledge and abilities required in the industry through learning process. The key assumption underlying this relationship is that increased learning does, in fact, result in increased production processes and improved citizenship processes. Relationship 3 assumes that improvement in production processes lead to increased earnings at both individual and organizational level, and an equally important human capital relationship is that between the citizenship processes which is also affected by education (e.g., community involvement, voting) and enhanced social efficacy.

The theory supports the claim that those who have invested in university education will see a return on this effort by way of enhanced salaries. This has been attributed to employers paying more for individuals with the desired skills, knowledge and education (Louise, 2013). This claim however is rather idealistic as it assumes a situation of full employment where employers are competing for such highly educated and skilled employees. In developing economies like Kenya characterized by high level of unemployment, graduates may find it difficult to find suitable jobs and they may be forced to resort to venturing into starting their own businesses, accepting non-graduate jobs that pay less, going for experiential training or simply opt to remain unemployed (ibid).

From the foregoing explanation, it is clear that all parties in the relationship stand to benefit from higher education. The graduate employee benefits from earning competitive wages/salaries after acquiring the much sought skills, employers benefit because the enhanced productivity results in improved earnings while the citizenry benefits from education by becoming aware of their rights as citizens such as right to vote and so on.

In summary, the gaps that this research is trying to fill include measuring quality of university education in Kenya using non-traditional dimensions of quality of university education as suggested by Gibbs (2010) and authors of this work by triangulating the views of three groups of respondents; graduate students from selected public universities, graduate students from selected

\subsection{METHODOLOGY}

\subsection{Research design}

This paper is extracted from study that adopted triangular design approach. The design permits the study of research question/ problem from multiple points of view, thus providing a comprehensive way of addressing an issue (Rosenberg, Heimler and Morote 2012). In our case, quality and relevance of university education in Kenya was addressed from the perspective of employers. The others covered elsewhere were final year students from public and private universities.

\subsection{Population and Sample}

For purposes of getting information on employability skills of graduates (an indicator of quality and relevance of Kenyan university education), this study targeted all 86 employers registered in Kenya and operating in Kericho county.

Since the target population was manageable, a census on the entire population was carried out.

\subsection{Data collection instrument}

To obtain data on employability of graduates of Kenyan universities from the perspective of employers, the employer's version of Rosenberg, Heimler and Morote (2012) instrument was used. As the instrument was used without any modification, the need for establishing its validity and reliability was eliminated

\subsection{RESULTS AND DISCUSSION}

\subsection{Response Rates and Missing Value analysis}

Table 4.1 Response Rate

\begin{tabular}{llll}
\hline University & Expected & Received & Response rates \\
\hline Employers & 86 & 67 & $77.9 \%$ \\
\hline
\end{tabular}

From the employers a total of 67 responses were received back against the expected 86 representing $77.9 \%$ response rate as indicated in Table 4.1 .

Comparing the current response rates with recommendations by Saunders, lewis, and thornhills (2009) suggesting a 30-40\% response, Sekaran \& Bougie (2010) advocating for a minimum of 30\%, and Mugenda and Mugenda (2003) recommending response rates of more than $50 \%$ as adequate, $60 \%$ as good and above $70 \%$ rated very good, we therefore found the response rate for this study to be very good and therefore adequate for the study

\subsection{Exploratory Factor Analysis}

4.2.1 Employer's Perspective

The adoption of Rosenberg, Heimler and Morote (2012) questionnaire in assessing employability of Kenyan university graduates from an employer's perspective, was anchored on testing eight skills and competencies 
desired among work ready graduates. With a total of 67 valid questionnaire received back, each rating forty seven (47) items, a correlation matrix, a prerequisite to principal component analysis could not be identified. As a rule of thumb, a minimum of 1: 5 ratio of item to responses is required for component extraction to happen. In recognition of this short coming, the initial components defined by Rosenberg, Heimler and Morote (2012) were adopted in all subsequent analysis.

\subsection{2: Distribution of the sampled firms by sector \& Ownership}

Both manufacturing and service sectors in Kenya continues to offer employment opportunities for graduates. Kericho County being predominantly an agricultural zone makes agricultural production and processing a dominant economic activity. However, there are other sectors that feature which provide employment opportunities to graduates, albeit in small numbers. The distribution of the sixty seven (67) firms operating within Kericho County that responded in the study were as seen in Table 4.2

\section{Table 4.2: Distribution of Employers per Sector}

\begin{tabular}{lcc}
\hline Industry & Frequency & Percent \\
\hline Transport & 5 & $7.46 \%$ \\
Financial institutions & 22 & $32.85 \%$ \\
Manufacturing/ Food Processing & 21 & $31.34 \%$ \\
Health & 9 & $13.43 \%$ \\
Hospitality & 4 & $5.97 \%$ \\
Insurance & 6 & $8.96 \%$ \\
\hline
\end{tabular}

As would be expected, close to a third (31.34\%) of the firms surveyed were manufacturing or food processors. Financial institutions, a critical sector that supports the manufacturing and food processing accounted for $32.85 \%$ of the responses received. Four other support services namely; insurance, transport, health and hospitality accounted for the remaining $35.81 \%$ of the responses received as presented in Table 4.2. The distribution of the responses received is a reflection of an agricultural centered economy surrounded by critical support services necessary for smooth running of the sector and a close mirror of the Kenya economy.

The ownership of the sample firms were dominated by local ownership accounting for close to three quarters $(73.1 \%)$ with the remaining firms, a majority of who were multinationals owned by foreigners.

Table 4.3: Ownership structure of Samples firms

\begin{tabular}{lcc}
\hline Ownership & Frequency & Percent \\
\hline Foreign & 18 & 26.9 \\
Local & 49 & 73.1
\end{tabular}

\subsection{3: Specialization of Graduates Employed}

The departmentalization of organizations based on core functions calls for graduates with different specialization presenting graduates from public universities with employment opportunities. The area of specialization of graduates engaged by employers in Kericho County is diverse as seen in Table 4.4.

Table 4.4: Specialization of graduates employed

\begin{tabular}{lcc}
\hline Graduates Specialization & Frequency & Percent \\
\hline Finance \& Accounting & 34 & $50.7 \%$ \\
Marketing & 19 & $28.35 \%$ \\
Human Resource & 25 & $37.31 \%$ \\
Information Technology & 12 & $17.9 \%$ \\
Health sciences & 9 & $13.43 \%$ \\
Others & 37 & $55.2 \%$ \\
\hline
\end{tabular}

The type of graduates employed in the sampled firms cut across all specialization with half (50.7\%) engaging accounting and finance graduates, slightly more than a third (37.31\%) employing human resource graduates with information technology and health sciences graduates being the least employed among the dominant graduate employment opportunities. This was an indication that university graduates from diverse specializations were given employment opportunities by the sampled firms. This also meant that employers were knowledgeable of the quality of graduates from Kenya universities and their responses were reflective of their true experience. 


\subsection{Graduate Employability from Employers Perspective}

The objective of every university is to produce graduates who are ready to take up employment opportunities arising from the productive sectors of the economy. To assess the quality of the graduates, six areas assessing employability of universities graduates were used. A summary of their responses were as seen in Table 4.5.

Table 4.5. Employers' Assessment of Graduates' Employability

\begin{tabular}{|c|c|c|c|c|c|c|c|}
\hline Response & SD & D & N/I & $\mathbf{A}$ & SA & Mean & Chi Square \\
\hline $\begin{array}{l}\text { 1. Would recommend to other } \\
\text { employers to employ Kenyan } \\
\text { universities graduates }\end{array}$ & $\begin{array}{c}0 \\
(0.0 \%)\end{array}$ & $\begin{array}{c}6 \\
(8.9 \%)\end{array}$ & $\begin{array}{c}33 \\
(49.3 \%)\end{array}$ & $\begin{array}{c}12 \\
(17.9 \%)\end{array}$ & $\begin{array}{c}14 \\
(20.9 \%)\end{array}$ & 3.42 & $13.06^{* * *}$ \\
\hline $\begin{array}{l}\text { 2. Employing Kenyan graduates } \\
\text { was a wise decision }\end{array}$ & $\begin{array}{c}0 \\
0.0 \%)\end{array}$ & $\begin{array}{c}2 \\
(3.0 \%)\end{array}$ & $\begin{array}{c}26 \\
(38.8 \%)\end{array}$ & $\begin{array}{c}31 \\
(46.3 \%)\end{array}$ & $\begin{array}{c}8 \\
(11.9 \%)\end{array}$ & 3.95 & $14.00 * * *$ \\
\hline $\begin{array}{l}\text { 3. Satisfied with the decision to } \\
\text { employ Kenyan Graduates }\end{array}$ & $\begin{array}{c}0 \\
(0.0 \%)\end{array}$ & $\begin{array}{c}0 \\
(0.0 \%)\end{array}$ & $\begin{array}{c}11 \\
(16.4 \%)\end{array}$ & $\begin{array}{c}33 \\
(49.3 \%)\end{array}$ & $\begin{array}{c}23 \\
(34.3 \%)\end{array}$ & 4.28 & $14.36^{* * *}$ \\
\hline $\begin{array}{l}\text { 4. Will employ again graduates } \\
\text { from Kenyan universities } \\
\text { When need arises, }\end{array}$ & $\begin{array}{c}0 \\
(0.0 \%)\end{array}$ & $\begin{array}{c}1 \\
(1.5 \%)\end{array}$ & $\begin{array}{c}8 \\
(11.9 \%)\end{array}$ & $\begin{array}{c}32 \\
(47.8 \%)\end{array}$ & $\begin{array}{c}26 \\
(40.3 \%)\end{array}$ & 3.88 & $10.87 * * *$ \\
\hline $\begin{array}{l}\text { 5. Graduates have made } \\
\text { valuable contribution to the } \\
\text { organization }\end{array}$ & $\begin{array}{c}0 \\
(0.0 \%)\end{array}$ & $\begin{array}{c}0 \\
(0.0 \%)\end{array}$ & $\begin{array}{c}23 \\
(34.3 \%)\end{array}$ & $\begin{array}{c}33 \\
(49.3 \%)\end{array}$ & $\begin{array}{c}11 \\
(16.4 \%)\end{array}$ & 3.02 & $53.22 * * *$ \\
\hline $\begin{array}{l}\text { 6. The company gets value for } \\
\text { wages/salary paid to Kenyan }\end{array}$ & $\begin{array}{c}2 \\
(3.0 \%)\end{array}$ & $\begin{array}{c}1 \\
(1.5 \%)\end{array}$ & $\begin{array}{c}9 \\
(13.4 \%)\end{array}$ & $\begin{array}{c}30 \\
(44.8 \%)\end{array}$ & $\begin{array}{c}25 \\
(37.3 \%)\end{array}$ & 3.87 & $7.73 * * *$ \\
\hline
\end{tabular}
graduates

Key: SD- strongly disagree; D- disagree; N/I - Neutral/Indifferent; A - Agree \&

SA- strongly agree.

When individual attribute measuring different employability indicators were assessed, employers had a mixed response. Nearly a half $(49.3 \%)$ of the employers remained undecided on whether they would recommend Kenyan graduates to other employers, a likely worrying position in a country where thousands of graduates are released to the job market every year. Similarly, their evaluation of whether it was a wise decision to employ a Kenyan graduate and whether graduates employed within their firms have made valuable contribution was largely neutral but with a marginal greater number of employers in favor. Significant proportions of employers were however satisfied with their decision to employ Kenyan graduates and had a feeling that they are getting value from graduates already working in their firms. A possible explanation for this positive rating would be that graduates were better trainable at the workplace giving the employers an opportunity to inculcate skills valuable to their performance. The current finding, places Kenyan graduates at slightly above average in the employability continuum, a position that calls for further interventions if future graduates are to be job market ready.

4.4 Employers Assessment of Specific Employability Skills among Kenyan Graduates.

Based on the classification of employability skills adopted by Rosenberg, Heimler and Morote (2012), the following is a descriptive summary of these individual dimensions of quality as rated by the employers.

Table 4.6: Specific Employability Skills

\begin{tabular}{cll}
\hline & Extracted Factor & Items overall mean \\
\hline & & \\
1. & Basic Literacy \& Numerical Skills & 4.18 \\
2. & Critical Thinking & 3.62 \\
3. & Leadership Skills & 3.78 \\
4. & Management Skills & 4.24 \\
\hline 5. & Interpersonal skills & 4.02 \\
6. & Information Technology Skills & 4.12 \\
7. & Systems Thinking Skills & 4.03 \\
\hline 8. & Work Ethics & 3.94 \\
\hline
\end{tabular}

\subsubsection{Basic Literacy \& Numerical Skills}

Basic literacy and numerical skills are the most critical foundational learnt skills upon which other specialized skills are built. Inadequacy in basic literacy and numerical skills impedes the development of work-related skills. Majority of the employers agreed that Kenyan graduates were able to perform basic computations, communicate orally; present organized thoughts, locate, understand and interpret basic verbal messages as well as generate new ideas. Sifuna and Sawamura, (2010) noted that the influence of entry behavior of the students into university is immaterial and Kuh (2001) indicated that what students do during college counts more in terms of 
desired outcomes than who they are on entry thus it more likely that Kenya universities placed more emphasis on basic literacy \& numerical skills rather than applied skills desire at the workplace.

\subsection{2: Critical Thinking}

The ability to deliver in challenging work settings depends on the ability of employees to critically analyze and develop the right perspectives that will lead to optimal choices.

The overall mean score for critical thinking skills of 3.624 an indication that respondents on average, agreed that Kenyan graduates were able to specify goals, constraints and generate alternative solutions, Recognize problems and give advice, organize and process information, acquire and apply knowledge \& skills and discover a rule or principle underlying relationships. A look at individual assessment areas of critical thinking, close to half of the employers were in agreement that graduates employed in their firms could specify goals and develop solutions, acquire and apply knowledge and relevant skills at a scale that is slightly higher than average. The ability to recognize problems \& give advice, process and organize information and discover a rule or a principle underlying relationships received a relatively lower rating with most employers remaining undecided. Critically, it can be seen from employers rating that graduates in their firms were less empowered in skills necessary for critical analysis and those required in problem solving. A relatively favorable rating on their ability to acquire skills and new knowledge confirms the earlier proposition that Kenyan graduates were open to learning at the work place based on their strong foundational skills of literacy and numeracy.

\subsubsection{Leadership Skills}

Graduates are more likely to take up leadership roles as they progress to managerial positions to oversee and provide direction to lower level employees. Leadership is a skill rated as the most important when future managerial potential is taken into account. Despite this recognition it does not feature prominently in most educational curriculum Pellegrino and Hilton (2012).

It is evident, based on a leadership mean score of 3.78 that employers were in agreement that Kenyan graduates have the required leadership skills at their workplace. A look at individual leadership attributes, graduates are faced with a challenge in defining their self-worth and communicating their ideas, justify, persuade or convince others on a matter. Their perseverance towards achieving goals, setting their personal goals and choosing an ethical course remains average. A poor rating by employers on graduate' own perception of their self-worth and their ability to effectively communicate dents the leadership abilities of the graduates joining the employment in Kenya and a call for urgent redress.

National Association of Colleges and Employers (NACE) (2013) in Israel ranked leadership as second on a list of desired attributes required of graduates seeking employment and reports that 76 percent of industry seek evidence of leadership skills on graduates' résumés. More than Fifty per cent of companies are looking for leadership skills when recruiting new graduates, warning that any perceived leadership deficit is likely to impede confidence in any decision to employ a graduate, a position that Kenyan employers are likely find themselves in.

\subsubsection{Management Skills}

In addition to equipping learners with skills in their areas of specialization, universities are expected to incorporate managerial skills as part of learning outcomes in their curriculum. Therefore, it is mandatory for curriculums to have learning content that will inculcate these skills in graduates.

Employers were on average in strongly agree that Kenya graduates command relatively good management skills. More than half of the employers noted that graduate employees in their organizational were able to allocate, rank, prepare and follow schedules, use budgets, forecast and adjust them based on objectives, can acquire store and allocate space efficiently and can assess employee skills and distribute work accordingly. While this finding may be positive, much need to be done. With continued criticisms leveled against universities as being too detached from industry, being more concerned with theory rather than practice and reliance on staff with limited experience in the private sector (Kilika,, K'Obonyo, Ogutu, \& Munyoki,, 2016), a need for stronger university-industry linkages must be explored going forward as a channel in which graduates are to gain better and work centered managerial skills.

\subsubsection{Interpersonal skills}

One of the most sought after attributes by employers is the ability of an employee to interact with others in manner that foster teamwork and collaboration.

On average, employers ranked interpersonal skills of their graduate employees at a mean score of 4.02, an indication that the employers agreed that Kenya graduates are able to effectively contribute to group efforts, help other staff members learn, meet customer expectations, Work towards agreements involving the exchange of resources, resolve divergent views, interact with members of diverse backgrounds, demonstrate friendliness, understanding and empathy towards other employees. These finding has a strong indication limited soft skills among the Kenyan graduates.

Going by what is depicted by the employers and the changing structure of the contemporary workplace, symbolized by increasingly diversity and the use of project, cross-functional groups, and even virtual teams in 
the workplace, Kenya university graduates are likely to keep up workplace demands if their level of interpersonal skills remains high.

\subsubsection{Information Technology Skills}

Increased use of information technology and automation of the workplace has raised the need for graduates with more than the basic IT skills. Deployment of these skills in solving workplace challenges and improving performance continues to be a desired attribute by most employers.

A mean score of 4.12 is an indication that employers on average strongly agreed that Kenyan graduates are adequately endowed and can apply IT skills in their workplaces. IT skills ranks relatively higher compared to most of the other dimensions assessed in the study. In all the seven attributes used to assess IT skills, majority of the employers placed graduates at satisfactory levels in their ability. The tremendous growth in the IT sector in the country and the government's efforts in promoting Information Technology as catalysis for job creations could be bearing fruits if the current employer's response is anything to go by.

\subsubsection{Systems Thinking Skills}

The ability to view, analyze and improve the working of systems in the workplace is critical for employees taking up managerial positions and those playing a critical role in running the day to day operations in any firm seeking competitiveness.

On average, employers agreed that Kenyan university graduates were endowed with system thinking skills. Graduate ranked highly in understanding how social, technical and organizational system were working but were less endowed in distinguishing trends and predicting the impact of actions on systems operations. Employers were on average agreed that graduates were able to make suggestions to improve existing products or services, assess efficiency of operations, could recognize efficient operations and understand interactions and relationships of systems in a global economy but were undecided on the ability of the graduates to understand interactions and relationships of systems within an organization.

\subsubsection{Work Ethics}

The performance of graduates at the workplace requires them to develop a right attitude towards the roles and responsibilities. Employers expects that engagement at the work place will be employee driven, each committing themselves to achieving both individual and group goals.

On average, employers agreed that graduate employees in their firms had the desired work ethics. They agreed that they attended required meeting and events, achieve both organizational and individual goals, complete work assigned on time and were adaptable to their work environment. Employers on average agreed that graduates were commited to attending organizations meetings on time, understand organizations protocols and procedures, and display of a positive work attitude. An average rating of 3.94 from employers is an indication that on average Kenyan university graduates were adequately prepared for the work environment

\subsection{Hypothesis Testing}

From the employer's perspective the study hypothesized that skills acquired by Kenya university graduates do not significantly influence their employability.

A linear regression model was fitted on data from 67 employers with eight variables significantly explaining $48.8 \%$ of the variances in employability score when the number of explanatory variables was accounted for in the model.

Table 4.7: Employability Regression Model Summary

\begin{tabular}{ccccc}
\hline R & R Square & $\begin{array}{c}\text { Adjusted R } \\
\text { Square }\end{array}$ & $\begin{array}{c}\text { Std. Error of the } \\
\text { Estimate }\end{array}$ & Durbin-Watson \\
\hline 0.742 & 0.550 & 0.488 & 1.416 & 2.015 \\
\hline
\end{tabular}

With the model and the data meeting all the linear regression assumption test, only four dimensions of quality and relevance were found to be significant. Interpersonal skills were the most significant dimension in predicting employability of Kenyan graduates. This skill had the highest predictive power accounting for $25.8 \%$ of the variation in the employability score. Closely, basic literacy and numerical skills had the second highest predictive power, explaining $21.4 \%$ of the variances in the employability score, an indication that most employers were more concerned with foundational skills for onwards retraining in-line with their organizational specific need. 
Table 4.8: Employers Regression Model Coefficient Estimates

\begin{tabular}{|c|c|c|c|c|c|c|}
\hline & \multicolumn{2}{|c|}{$\begin{array}{l}\text { Unstandardized } \\
\text { Coefficients }\end{array}$} & \multirow{2}{*}{$\begin{array}{c}\text { Stdz } \\
\text { Coeff } \\
\text { Beta }\end{array}$} & \multirow[b]{2}{*}{$\mathrm{t}$} & \multirow[b]{2}{*}{ Sig. } & \multirow[b]{2}{*}{ VIF } \\
\hline & $\mathrm{B}$ & Std. Error & & & & \\
\hline (Constant) & -3.009 & 3.127 & & -.962 & .340 & \\
\hline Literacy \& Numerical skills & .214 & .076 & .272 & 2.801 & .007 & 1.212 \\
\hline Critical Thinking & .176 & .075 & .249 & 2.351 & .022 & 1.449 \\
\hline Leadership Skills & .073 & .066 & .117 & 1.112 & .271 & 1.418 \\
\hline Management Skills & .075 & .093 & .077 & .809 & .422 & 1.174 \\
\hline Interpersonal Skills & .258 & .074 & .339 & 3.506 & .001 & 1.204 \\
\hline IT Skills & .054 & .049 & .110 & 1.106 & .273 & 1.283 \\
\hline Systems Thinking & -.016 & .050 & -.035 & -.312 & .756 & 1.659 \\
\hline Work Ethics & .191 & .071 & .321 & 2.686 & .009 & 1.847 \\
\hline
\end{tabular}

Work ethics significantly explained $19.1 \%$ of the variations in the employability score, an indication of the need for universities to strongly inculcate a working mentality among its graduates. Critical thinking was the last dimension that had significant influence on the employability of graduates from the employer's perspective explaining $17.6 \%$ of the variations in the employability score. Intuitively, this denotes a preference for analytical and problem- solving capabilities among the graduates in the context of challenging modern work environment.

The strong emphasis by employers on work ethics points to an increasing concern on the number of graduates who are ready to condone corruption and unethical behavior, unconvinced that hard work brings success (Awiti \& Scott, 2016). A positive attitude and flexibility to work have been shown in the literature as key attributes that employers look for in graduates (Corporate Staffing Services, 2015). It is of interest that universities put in more efforts in inculcating the right work ethics in preparation of their graduates for the workplace.

To examine if the employability of Kenyan graduates was influenced by the skills acquired at the university levels, a null hypothesis holding that skills acquired by graduates in private and public universities in Kenya do not influence their employability was tested. Analysis of Variance (ANOVA) test results were as shown in Table 4.9.

\begin{tabular}{|c|c|c|c|c|c|}
\hline 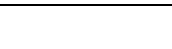 & Sum of Squares & df & Mean Square & $\mathbf{F}$ & Sig. \\
\hline Regression & 142.328 & 8 & 17.791 & 8.873 & 0.000 \\
\hline Residual & 116.299 & 58 & 2.005 & & \\
\hline Total & 258.627 & 66 & & & \\
\hline
\end{tabular}

The resulting ANOVA test results $(\mathrm{F}=8.873)$ with a $\mathrm{p}$ Value of less than 0.05 , was an indication that the estimated coefficients of the eight skills tested in the study were significantly different from zero. Consequently, the null hypothesis was rejected and a conclusion that one or a combination of the skills tested was significantly influencing the levels of employability of graduates from private and public university in Kenya was adopted. The conclusion therefore confirms the significance of Literacy \& Numerical, Critical Thinking, Interpersonal skills and Work Ethics as core to employability of university graduates in Kenya. In view of the findings of Rintari (2017) where employability skills were found to be positively correlated with present job competence, job confidence and job involvement, it is important that policy makers in the University education in Kenya should consider inculcating more of the non-technical skills into their curriculums for improved employability.

\subsection{SUMMARY, CONCLUSION \& RECOMENDATIONS}

\subsection{Summary of Findings}

The objective of this study sought to establish the skill set influencing employability of graduates from private and public universities in Kenya from employer's viewpoint. The participating employers from Kericho County were drawn from different sectors dominated by Agri-processing and financial services. Other sector included health, insurance, transport and hospitality. Two third of the employer organizations who participated in the study were locally owned drawing their graduate employees from different areas of specialization.

The employability of graduates from universities in Kenya based on employer's assessment was slightly above average with majority undecided on whether they would recommend other employers to consider engaging Kenyan graduates. Employers were confident in their decision to employ current graduates and when need arises they will still employ graduates from Kenyan universities. They also agreed that they get value for the salaries and other compensations they paid to graduate employees from Kenyan universities. The 
employability of graduates from both private and public universities in Kenya was significantly influenced by their Literacy \& numerical skills, critical thinking skills, interpersonal skills and their work ethics. Notable, systems thinking skills were found to negatively influence the employability of graduates.

\subsection{Conclusions}

Employers, the direct consumers of the graduates from universities in Kenya holds a positive view towards the levels of employability among Kenyan graduates, contrary to the generally held belief that Kenyan graduates are ill prepared to face the challenges in the work industry. It is the expectation of most employers that university graduates joining the labor market must possess all relevant skills that will allow them to effectively deliver in their assigned role and responsibilities. Most employers on average are in agreement that graduates from Kenyan universities have good critical thinking skills, leadership skills, management skills, interpersonal skills and work ethics with majority of these skills being critical in modern day workplace.

Lastly, based on employer's assessment of graduates in their workplaces, literacy and numerical skills, critical thinking skills, interpersonal skills and work ethics dominates the skills that are shaping the employability of Kenyan graduates. It is also evident that soft skills are dominating the skill set desired by employers and calls for effort in ensuring that such skills are fully integrated into the university curriculum if the perceived skill mismatch between university education and industry is to be eliminated. A higher rating of graduates in Literacy \& numerical skills is an indication of a strong foundation in Kenyan graduates on which employers build upon technical skills unique to their individual needs. Strong rating on IT skills is a strong indicator of the government aggressive IT policy coming to fruition, a resource that employers must be ready to fully exploit.

Evidence from the current study on the employability of graduates from both private and public universities, partially supports the concerns raised by employers and the society that graduates are ill prepared to meet the needs of the industry.

\subsection{Recommendations}

In recognition that not every graduate will be an entrepreneur, inculcating the right skills going forward will be critical for graduates to remain employable. While most universities in Kenya are more focus on training graduates who are skilled in their technical areas and specialization, more focus should be on soft skills. Dynamic changes in modern work environment places more emphasis on a set of soft skills. Interpersonal skills, right work ethics, leadership skills, effective communication, critical thinking and problem solving skills remains to be the most desired skills and calls for the integration of such skills in to university curriculum.

\subsection{Suggestions for further Research}

A limited number of employers participated in the study, limiting instruments structural tests. A bigger and a diverse group of employers would likely be of interest in improving quality of the findings

\section{REFFERENCES}

Abagi O., Nzomo J. And Otieno W. (2005) Private higher education in Kenya, International institute for Education Planning

Amimo, C. A. (2012). Tailoring higher education in Kenya to the demands of the postindustrial workplace. Baraton Interdisciplinary Research Journal, 2 (1), 52-58.

Armstrong M, 2006, A handbook of human resource management, $10^{\text {th }}$ edn, Kogan Page Limited, london Uk

Awiti A, \& Scott, B, (2015) East Africa Youth Survey. East Africa Institute, Aga Khan University, Nairobi, Kenya.

Bontis, N, Dragonetti, N C, Jacobsen, K and Roos, G (1999) The knowledge toolbox: a review of the tools available to measure and manage intangible resources, European Management Journal, 17(4), pp 391-402

Candy, P. C. \& Crebert, R. G., (1991) 'Ivory tower to concrete jungle. The difficult transition from the academyTo the workplace as learning environments', Journal of Higher Education, 62(5), pp. 570-92.

Corporate Staffing Services (2015) Hiring: Trends, Challenges and Future Outlook. Quarter One Talent Report. Nairobi. Corporate Staffing Services.

Gibbs G. (2010) Dimensions of quality. The higher education academy, ISBN 978-1-907207-24-2

Humburg M. Van der Velden R. \& Verhagen A (2013). The Employability of Higher education graduates: The Employers' Perspective, Research Centre for Education and the Labour Market, the Netherlands.

IEC (2015) Understanding Employers' Graduate Recruitment and Selection Practices: Main report,

Kilika,J. M, K'Obonyo, P.O, Ogutu, M. \& Munyoki, J.M (2016) The mediating role of university industry collaboration on the relationship between human resource development, infrastructure and performance of universities in Kenya. Asia Pacific Institute of Advanced Research (APIAR). Vol 2 (1).

KNBS (2016) Economic survey 2016, Republic of Kenya, ISBN:9966-767-54-1 
Kuh (2001) The National Survey of Student Engagement: Conceptual Framework and Overview of Psychometric Properties Bloomington, IN: Indiana University Center for Postsecondary Research and Planning

Louise C L J, (2013) Investigating Employability: the Perspective of the Business School Graduate , Unpublished $\mathrm{PhD}$ thesis

National Association of Colleges and Employers (NACE) (2013), Job Outlook 2014, NACE, Bethlehem, PA.

Nyangau, J. Z. (2014). Higher Education as an Instrument of Economic Growth in Kenya. FIRE: Forum for International Research in Education, 1(1). Retrieved from http://preserve.lehigh.edu/fire/vol1/iss1/3

Oanda I and Sifuna D, (2016) 'Divergent Narratives on Graduate Employability in Kenya' in McCowan et al (eds), Universities, Employability and Inclusivity: Repositioning Higher Education in Ghana, Kenya, Nigeria, and South Africa.

OECD (2012), Education Today 2013: The OECD Perspective, OECD Publishing

OECD (2014), Education at a Glance 2014: OECD Indicators, OECD Publishing.

Oztruk I. (2001). The role of education in economic development: A theoretical perspective, Journal of Rural Development and Administration, Volume XXXIII, No. 1, Winter 2001, pp. 39-47.Programs. New York: Macmillan.

Rintari, N. G. (2017) University Graduates’ Employability Skills Preparedness in Kenyan Economic Sectors. European Journal of Business and Management Vol.9, No.12,

Rosenberg S, Heimler R and Morote, E (2012) Basic Employability Skills: A Triangular Design Approach, Education+Training Vol 54, No. 1, pp.7-20

Saunders, M., Lewis, P. \& Thornhill, A. (2009) Research methods for business students, 5th ed., Harlow, Pearson Education

Sekaran, U., \& Bougie, R. (2010). Research methods for business: A skill building approaches (5th ed.). West Sussex,UK: John Wiley \& Sons Ltd.

Sifuna D \& Sawamura N(2010) Challenges of Quality Education in Sub-Saharan African Countries, NovaScience Publishers

Theodore R.(2012), The Role of Education in Economic Development: Theory, History, and Current Returns

Tomlinson M. (2008) 'The Degree Is not Enough': Students' Perceptions of the Role of Higher education credentials for Graduate Work and Employability, British Journal of Sociology of Education, Vol. 29, No. 1 (Jan., 2008), pp. 49-61

Ume-amen (2014) Employer's Expectations Versus Performance of Fresh Graduates, Market forces, College of management science, VOL IX, NO 2

UNESCO, 2012. Graduate Employability in Asia, Bangok, 978-92-9223-395-2(Electronic Version)

Washer, P. (2007) 'Revisiting Key Skills: A Practical Framework for Higher Education', Quality in Higher Education, 13: 1, $57-67$

World Bank (2014) 'Youth Employment in Sub-Saharan Africa: Africa Development Forum'. Washington: World Bank. 